\title{
Keeping up with the information explosion: a surge in consumption of data on pediatric SARS-CoV-2 infection by pediatric emergency physicians
}

\author{
Oren Feldman ${ }^{1}$, Amit Boukai ${ }^{2}$ and Itai Shavit ${ }^{1,3^{*}}$ (D)
}

\begin{abstract}
PEM-Database.org is an unaffiliated, not-for-profit website, dedicated to the field's advancement of pediatric emergency medicine. PEM-Database published the first early access pediatric-related SARS-CoV-2 articles on March 13th, two days following the World Health Organization's declaration of a global pandemic. Over the following 2 weeks, the number of PEM-Database entries increased dramatically. This surge expresses interest by pediatric emergency medicine physicians in data on pediatric SARS-CoV-2 infection.
\end{abstract}

Keywords: SARS-CoV-2, Pandemic, Pediatrics

To the Editor,

PEM-Database is a well-known online evidence-based resource for professionals practicing pediatric emergency medicine and is an unaffiliated, not-for-profit website, dedicated to the field's advancement (http://www.pemdatabase.org/) [1]. PEM-Database is regularly updated with references to strictly academic and peer-reviewed material, such as pediatric emergency medicine abstracts, articles, and international guidelines published in the scientific literature, and is widely cited in leading pediatric and emergency medicine books [2-4]. The database is consistently edited and monitored by leading North American and European researchers [5]. The emergence of a coronavirus illness not previously seen in humans, called coronavirus disease 2019 (COVID-19), has captured the attention of the world. During December 2019, a series of pneumonia cases of an unknown origin were first identified in the city of Wuhan, Hubei, China. On December 31, 2019, China reported its outbreak to the World Health Organization, and shortly thereafter, the responsible pathogen was identified as a novel coronavirus, called SARS-CoV-2 due to its sequence similarity with the virus causing severe acute respiratory syndrome (SARS). By the end of February, a surge of cases spread throughout Europe and the USA, followed by an official declaration by the World Health Organization of a global pandemic on March 11, 2020. By March 28th, more than 645,000 cases of COVID-19

* Correspondence: itai@pem-database.org

${ }^{1}$ Pediatric Emergency Department, Rambam Health Care Campus, Haifa, Israel ${ }^{3}$ Kibutz Maayan Tzvi, Israel

Full list of author information is available at the end of the article 


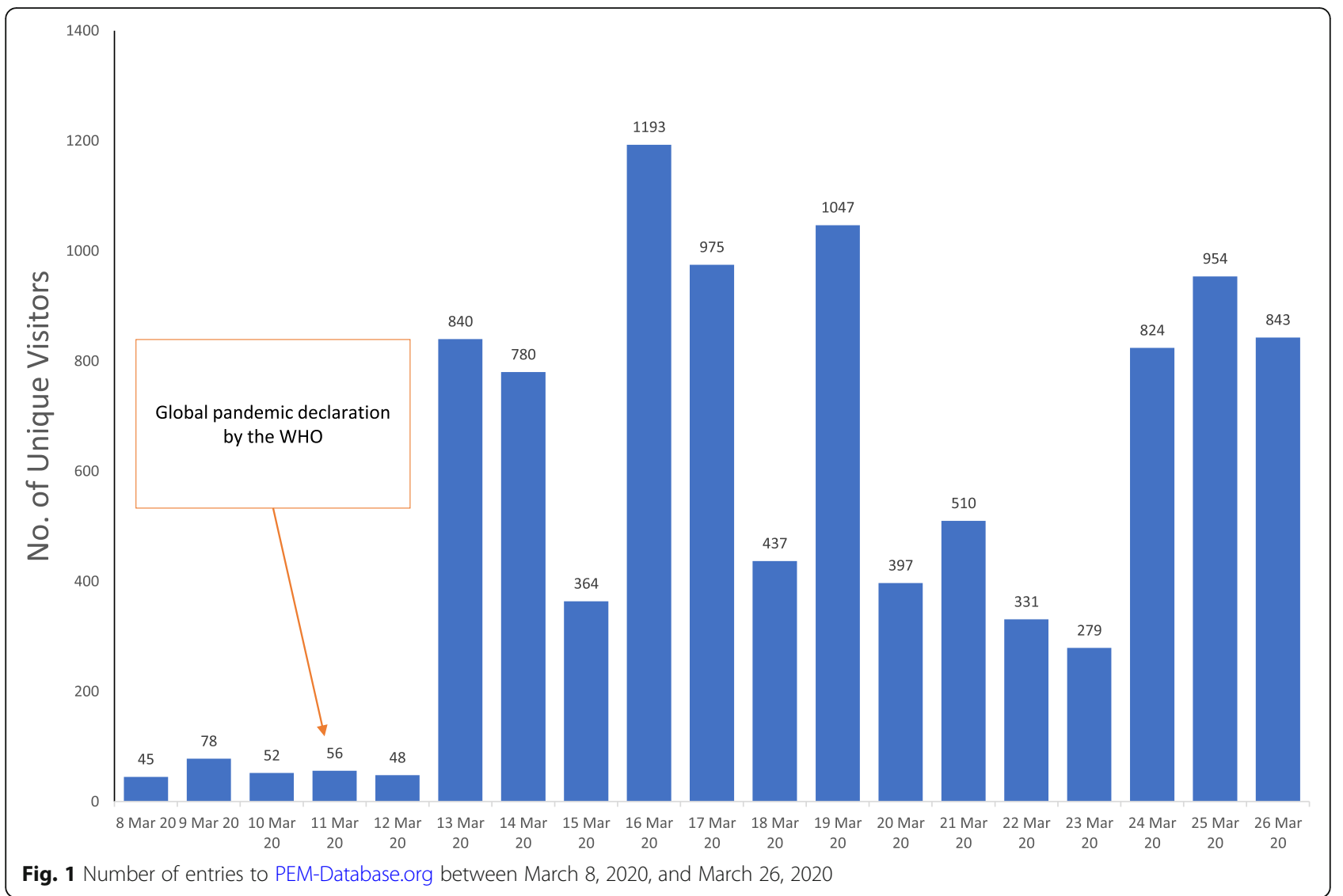

had been reported in over 190 countries and territories, with approximately 29,900 deaths [6].

PEM-Database published the first early access pediatric-related COVID-19 articles on March 13th, 2 days following the World Health Organization's declaration. Until then, the website had a stable entry log ranging from 40 to 80 entries per day. Yet, over the following 14days, the number of entries increased to a maximum of 1193 entries per day, with an average $1240 \%$ higher than the previous week (Fig. 1). Nearly $45 \%$ of the site's recent visitors were from the USA alone, and a combined $14 \%$ of entries were by physicians from Italy, Spain, France, and Canada, all of which are countries facing an outbreak. We believe that there is no other possible explanation for this surge other than a clearly specific interest by pediatric emergency medicine physicians in data on COVID-19 in children. Articles published on PEM-Database.org are strictly pediatric related; therefore, this increase in entries does not reflect a general interest in COVID-19 or in information about the illness in adults. This observed spike in entries to PEM-Database suggests that there is a great need and interest for up-to-date information on pediatric presentations of SARS-CoV-2 among pediatric emergency medicine physicians.

\section{Abbreviations \\ COVID-19: Coronavirus disease 2019; SARS: Severe acute respiratory} syndrome

\section{Acknowledgements \\ Not applicable}

\section{Authors' contributions}

OF drafted the manuscript, analyzed and interpreted the data, and reviewed the literature. $A B$ abstracted the data, reviewed the literature, carried out the initial analysis, and critically reviewed the manuscript. IS conceived the idea for the study, analyzed and interpreted the data, reviewed the literature, and critically reviewed the manuscript. IS has full access to all the data in the study and takes responsibility for the integrity of the data and the accuracy of the data analysis. All authors approved the final manuscript as submitted and agree to be accountable for all aspects of the work.

\section{Funding \\ No funding was received for the study.}

\section{Availability of data and materials}

All data is included in the paper and table.

\section{Ethics approval and consent to participate}

Not applicable

\section{Consent for publication}

Not applicable

\section{Competing interests}

The authors declare that they have no competing interests. 


\section{Author details}

'Pediatric Emergency Department, Rambam Health Care Campus, Haifa, Israel. ${ }^{2}$ Rappaport Faculty of Medicine, Technion-Israel Institute of

Technology, Haifa, Israel. ${ }^{3}$ Kibutz Maayan Tzvi, Israel.

Received: 7 April 2020 Accepted: 5 May 2020

Published online: 19 May 2020

\section{References}

1. PEM Database Online. Available at URL: http://www.pemdatabase.org/. Accessed on April 4, 2020.

2. Wright JL, Krug SE. Emergency medicine and critical care: emergency medical services for children. In: Nelson's textbook of pediatrics (21st ed., p. 524). Philadelphia, PA: Elsevier Inc; 2020.

3. Tintinalli JE, Cameron P, Holliman CJ. EMS: a practical global guidebook. Shelton, CT: Peoples Med. Publ. House; 2010. Available at URL: https://books. google.co.il/books?id=MtBlevPHBCgC\&pg=PA656\&lpg\# $v=$ =nepage\&g\& $f=$ false. Accessed on April 4, 2020.

4. Auerbach, P. S. (2016). Pain management and procedural sedation in infants and children. In Tintinalli's emergency medicine: a comprehensive study guide (8th ed.). Available at URL: https://accessmedicine.mhmedical.com/ content.aspx?bookid=1658\&sectionid=109431987\&jumpsectionid=109432 005\#1121506951. Accessed on April 4, 2020.

5. PEM Database Online editorial board. Available at URL: http://www. pemdatabase.org/EDITORIALBOARD.html. Accessed on April 4, 2020.

6. World Health Organization. Coronavirus disease (COVID-19) outbreak (https://www.who.int.)

\section{Publisher's Note}

Springer Nature remains neutral with regard to jurisdictional claims in published maps and institutional affiliations.

Ready to submit your research? Choose BMC and benefit from:

- fast, convenient online submission

- thorough peer review by experienced researchers in your field

- rapid publication on acceptance

- support for research data, including large and complex data types

- gold Open Access which fosters wider collaboration and increased citations

- maximum visibility for your research: over $100 \mathrm{M}$ website views per year

At BMC, research is always in progress.

Learn more biomedcentral.com/submissions 